\title{
CORRECTIVE ACTION UNDER THE ANTITRUST LAWS
}

\author{
ARNE C. WIPRUd*
}

For several years prior to March 26, $1945,{ }^{1}$ a widespread controversy raged in and out of Congress over the applicability of the antitrust laws to private companies operating public transportation services, particularly railroad companies. This controversy arose out of investigations instituted by the Department of Justice, through its Antitrust Division, into certain alleged restrictive practices in the transportation field. These investigations culminated in the filing of a number of antitrust suits, the largest of which is the Association of American Railroads conspiracy case. ${ }^{2}$ Fuel was added by the filing of an original suit in the Supreme Court of the United States by the State of Georgia against eastern and southern railroads, charging a pricefixing conspiracy in violation of the antitrust laws. ${ }^{3}$ Practically all railroads in the United States, and their principal associations, are involved in these antitrust suits.

Under the circumstances, it was not surprising that the railroad industry produced the most ardent objectors to antitrust enforcement in the transportation field. The arguments of their spokesmen can be thus summarized: Decisions of the Supreme Court at the turn of the century, holding that railroads were subject to the antitrust laws and that noncompetitive rate-making was prohibited by those laws, ${ }^{4}$ have been deprived of their initial vigor by subsequent amendments to the Interstate Commerce Act-that these decisions have become "patent anachronisms." Giving little or no consideration to subsequent decisions of the Court affirming these earlier decisions, ${ }^{6}$ they reasoned that the Interstate Commerce Commission's jurisdiction

- LL.B. I917, St. Paul College of Law. Member of the Minnesota, Illinois, New York, and District of Columbia Bars. Special Assistant to the Attorney General of the United States, Chief of the Transportation Section, Antitrust Division, Department of Justice, I941-r945. Formerly lecturer on transportation, University of Minnesota. Author of Justice in Transportation (1945). Contributor to legal and political science periodicals.

IOn that date the United States Supreme Court rendered its decision on motion of the State of Georgia for leave to file an amended bill of complaint. Georgia v. Pennsylvania R.R., 324 U. S. 439 (1945).

${ }^{3}$ United States v. Association of American Railroads et al., 4 F. R. D. 510 (D. C. Nebr. I945).

${ }^{3}$ Georgia v. Pennsylvania R.R., cited supra, note $x$.

- United States v. 'Trans-Missouri Freight Ass'n, I66 U. S. 290 (1897); United States v. Joint Traffic Ass'n, I7I U. S. 505 (I898).

- Hearings before Senate Committee on Interstate Commerce on S. 942, Regulation of Rate Bureaus, 78th Cong., rst Sess. 957-970 (r943); Two Masters (1945), pamphlet by C. E. Johnston, Chairman, Western Association of Railway Executives; Charles D. Drayton, Transportation Under Two Masters 23 (1946).

"Notably the following: Northern Securities Co. v. United States, r93 U. S. 197 (1904); United States v. Union Pacific R.R., 226 U. S. 6I (IgI2); United States v. Southern Pacific Co., 259 U. S. 214 (I922); United States v. Socony-Vacuum Oil Co., 3 Io U. S. I50 (1940). In the Socony-Vacuum case, the Court held, affirming its decision in the United States v. Trenton Potteries Co., 273 U. S. 392 (r927), that the rule of reason does not protect combinations operating directly on prices or price structures even though the prices themselves are reasonable. 
and control over "every one of the activities" of carriers, particularly over their rates, was complete and therefore there was no area in which the antitrust laws could be applied. Thus the conclusion was reached that Congress had not made competition the keystone of its policy in transportation but had turned to regulation under the standards of the Interstate Commerce Act. ${ }^{7}$

The Department of Justice and the State of Georgia took the other view. ${ }^{8}$ They insisted that the early decisions of the Supreme Court had not been "repealed" by Congressional enactment; that the Commission's jurisdiction does not extend to all the activities of the carriers (a view also expressed by the Commission) $;^{\theta}$ and that competition within the framework of the regulatory act is still the policy of Congress.

On March 26, I945, the Supreme Court resolved these legal issues in its decision in Georgia v. Pennsylvania Railroad Company. ${ }^{10}$ While this decision was rendered pursuant to hearing on jurisdiction, the Court went farther and laid down the law which governs the substantive questions in the case. The case is in the course of trial.

The Court, adhering to its earlier decisions, held that regulated industries are not per se exempt from the Sherman Act; that railroads are subject to the antitrust laws; that conspiracies among carriers to fix rates are included within the broad sweep of the Sherman Act; that none of the powers acquired by the Interstate Commerce Commission since the enactment of the Sherman Act relates to the regulation of rate-fixing combinations; that the type of regulation which Congress chose did not eliminate the emphasis on competition and individual freedom of action in rate making; and that "the fact that the rates which have been fixed may or may not be held unlawful by the Commission is immaterial to the issue before us." On the latter point the Court stated:

The reason is that the Interstate Commerce Act does not provide remedies for the correction of all the abuses of rate-making which might constitute violations of the antitrust laws. Thus a "zone of reasonableness exists between maxima and minima within which a carrier is ordinarily free to adjust its charges for itself." United States v. Chicago M. St. P. \& P. R. Co., 294 U. S. 499,506 . Within that zone the Commission lacks power to grant relief even though the rates are raised to the maxima by conspiracy among carriers who employ unlawful tactics. If the rate-making function is freed from the unlawful restraints of the alleged conspiracy, the rates of the future will then be fixed in the manner

${ }^{7}$ Elmer A. Smith, Rate Making and the Antitrust Law, Railway Age, August 4, 1945; Hearings before the Senate Committee on Interstate Commerce on S. 942, Regulation of Rate Bureaus, 78th Cong., Ist Sess. 959-983 (r943).

${ }^{8}$ Hearings cited supra, note 7 , at 5-67; Hearings before Committee on Interstate Commerce on $H$. $R$. 2536, 79th Cong., and Sess. 739-767 (1946).

- The Interstate Commerce Commission states: "There is gross exaggeration in the idea that every act of the railroads is subject to regulation. The railroads have a large degrec of initiative in the making of their rates, and have freely made a multitude of reductions to meet competition. We have no power to control their passenger service. They select and pay their officers without supervision or hindrance. Nor do we undertake to tell them what equipment and supplies they may buy, how they shall operate their shops or maintain their tracks, what rails, ballast, and ties they shall use, what stations or other buildings they shall erect, what construction contracts they shall let, or how they shall manage their affairs in many other ways." 52 I.C.C. ANs. Rep. 7-8 (1938).

${ }^{10} 324$ U. S. 439 (1945). 
envisoned by Congress when it enacted this legislation. Damage must be presumed to flow from a conspiracy to manipulate rates within that zone.

... Any decree which is entered would look to the future and would free tomorrow's rate-making from the coercive and collusive influences alleged to exist. . . ${ }^{11}$

Again, on the nature of the proceeding as related to the functions of the Commission, the Court stated:

The present bill does not seek to have the Court act in the place of the Commission. It seeks to remove from the field of rate-making the influences of a combination which exceed the limits of the collaboration authorized for the fixing of joint through rates. It seeks to put an end to discriminatory and coercive practices. The aim is to make it possible for individual carriers to perform their duty under the Act, so that whatever tariffs may be continued in effect or superseded by new ones may be tariffs which are free from the restrictive, discriminatory, and coercive influences of the combination. That is not to undercut or impair the primary jurisdiction of the Commission over rates. It is to free the rate-making function of the influences of a conspiracy over which the Commission has no authority but which if proven to exist can only hinder the Commission in the tasks with which it is confronted. ${ }^{12}$

Thus, in all its broad sweep, the Court sustained the position of the State of Georgia and the Department of Justice. ${ }^{13}$

While the Georgia case involves an alleged conspiracy among railroads to fix rates, the antitrust laws have broader application in the transportation field. This is evident from the Court's opinion and the cases therein cited. And this view finds emphasis and illustration in the memorandum opinion of the District Court for the District of Nebraska, on motions to dismiss in United States $v$. The Association of American Railroads, ${ }^{14}$ rendered since the Supreme Court's decision in the Georgia case.

This case, commonly called the $A A R$ case, was instituted by the United States against the Association of American Railroads and other industry associations, fortyseven western railroads, two New York banking houses (J. P. Morgan \& Company, Incorporated, and Kuhn, Loeb \& Company), and sundry individuals who hold directorial or official positions with the several designated corporate and association defendants. Aside from the allegations charging a conspiracy among defendants and their co-conspirators to fix rates detrimental to the West, similar in nature to that charged by the State in the Georgia case as harmful to the South, the district

${ }^{12}$ Id. at $460-462$.

${ }^{22}$ Id. at $459-460$.

${ }^{12}$ In passing it should be noted that nothing in the minority opinion militates against the views thus expressed as applied to antitrust actions by the United States. On the contrary, the dissenting opinion states: "The support which the Department of Justice lends to Georgia's contentions by the brief amicus, filed in this Court in behalf of the United States, removes any evident need for entertaining this suit. The Government is charged with the enforcement of the antitrust laws, and is authorized by $\$ 4$ of the Sherman Act and $\$ 16$ of the Clayton Act to maintain suits for that purpose, which others cannot bring. If it believes that the alleged conspiracy exists and should be stopped by the remedial action of courts, without resort to the Commission, there would seem to be no reason why, avoiding the many technical obstacles to the present suit, it should not proceed to remedy in the usual manner the grievances of the citizens of the United States including citizens of Georgia." Id. at 489 .

${ }^{1 .} 4$ F. R. D. 510 (D. C. Nebr. 1945). 
court summarized in its opinion allegations in the complaint charging the conspirators with preventing the construction and introduction of sundry designated advantageous facilities for western shippers; impairing transportation services for western shippers by the arbitrary obstruction of connections and retarding of shipments, especially of perishable products destined to eastern points; exacting from western shippers certain unwarranted accessorial charges; preventing or deferring the installation for the benefit of western shippers and passengers of certain expedited service and improved equipment, and facilities and recreational opportunities for travelers; restricting solicitation of business by individual railroads; and preventing and postponing the development of competitive modes of transportation and travel, notably by motor trucks and motor buses. The district court continued:

The complaint sets out several illustrative examples of alleged conspiratorial collusion, furthered in some instances by coercive repression of individual conspiring carriers, in the maintenance at an unjustifiably high level of rates for the shipment of freight from, to or within the Western District; in the thwarting of competitive solicitation of low rate passenger traffic; in the exaction from shippers, and notably the plaintiff itself as a shipper of war materials, of extortionate and noncompetitive rates maintained by and in consequence of the combination and conspiracy; and in the artificial and improper manipulation of pipe line and rail rates for petroleum through conspiratory and repressive means. ${ }^{\mathbf{1 5}}$

The district court held, following reference to decisions of the Supreme Court applying the antitrust laws to "interstate common carriers by rail as well as by other means," that the charges in the complaint, "whose general outline has already been sketched, follow the reasonably consistent pattern of accusations under the Antitrust Act sustained in the numerous reported cases. And this is strikingly clear in respect of State of Georgia v. The Pennsylvania Railway Company."16

Thus have the courts again restated the Congressional policy of competition in the transportation field and given assurance that that policy, as embodied in the Sherman Act, is in aid of the functions of the Commission in its administration of the Interstate Commerce Act.

There are those in and out of the transportation industry, however, who express concern over the practical consequences if the State of Georgia and the Department of Justice prevail in their antitrust suits against that industry. Their concern seems to be largely with the application of the antitrust laws to rate making. What will happen if the rate bureaus are broken up? Will rate wars result? Are rate wars in the public interest? Is individual rate making by railroads a desirable feature in an industry characterized by huge investments and high overhead costs, one which is so strategic a part of the economy as to have an immediate effect upon the manufacturing, pricing, and distribution of virtually all consumer goods and services ? ${ }^{17}$

${ }^{15} \mathrm{Id}$. at $5 \times 6$.

${ }^{10} 1 d$. at 524 .

${ }^{17}$ Hearings before Senate Committee on Interstate Commerce on S. 942, Regulation of Rate Bureats, 78th Cong., Ist Sess. 831, 878, 938 (1943); Cherington. review of Wiprud, Justice in Transportatron, 59 Harv. L. REv. 821-824 (x946); Hearings before Senate Committee on Interstate Commerce on H. $R$. 2356, Regulation of Rate Bureaus, 79th Cong., 2nd Sess. I132 (1946); 58 I.C.C. ANN. Rep. 28-3I (r944). 
Those who pose these questions have assumed two basic fallacies: namely, that the contention is that rate bureaus are per se illegal, and that all carriers are required to make rates in a vacuum. These views find no support in the decisions of any court nor in the statements of any responsible public official.

As the Supreme Court stated in the Georgia case, "Under Section I(4) of the Interstate Commerce Act, it is 'the duty of every common carrier subject to this chapter to provide and furnish transportation upon reasonable request therefor, and to establish reasonable through routes with other such carriers, and just and reasonable rates, fares, charges and classifications applicable thereto.' And it is noted that agreement among carriers is provided in the establishment of joint rates. Section 6 ..."18 While the Court then held that "collaboration contemplated in the fixing of through and joint rates is of a restrictive [restricted?] nature" (the legitimate area of which it did not stop "at this stage of the proceedings to delineate"), that holding should be considered in relation to the Court's subsequent reference to decisions involving price-fixing under the Sherman Act and its statements on the nature of the relief which it envisaged in the Georgia case.

Referring to those cases wherein the Court held that price fixing is per se a violation of the Sherman Act, notably United States $v$. Socony-Vacuum Oil Co., ${ }^{19}$ the Court stated: "But we need not at this juncture determine the full extent to which that principle is applicable in the fixing of joint through rates."20 This further indication of a permissible area of collaboration in the making of such rates is emphasized in the discussion of relief. "It must be remembered," the Court stated, "that this is a suit to dissolve an illegal combination or to confine it to the legitimate area of collaboration." "Dissolution of illegal combinations or a restriction of their conduct to lawful channels is a conventional form of relief accorded in antitrust suits. No more is envisaged here"; ${ }^{22}$ and "We intimate no opinion whether the bill might be construed to charge more than [a conspiracy to use coercion in the fixing of rates and to discriminate against Georgia in the rates which are fixed] or whether a rate-fixing combination would be legal under the Interstate Commerce Act and the Sherman Act but for the features of discrimination and coercion charged here." 23

Thus has the Court recognized that Congress has given special consideration to the problems of rate making in the transportation field. Competition must be preserved by carriers within the zone of reasonableness. Individual freedom of action in rate making must not be interfered with. Agreements among carriers, however, are permissible in carrying out the Congressional mandate "to establish reasonable through routes with other such carriers, and just and reasonable rates, fares, charges and classifications applicable thereto." This mandate is found in the Interstate Commerce $\mathrm{Act}^{24}$ and, as the Court notes, section 6 of that Act provides for agreements

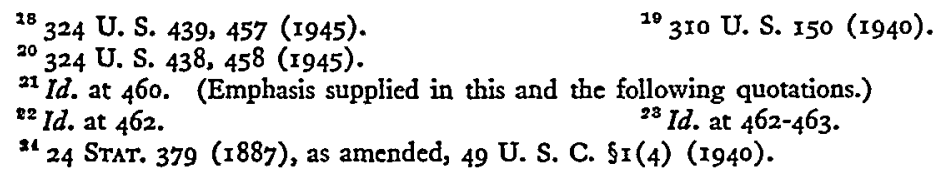


among carriers to effectuate its purpose. ${ }^{25}$ The Court, however, did not stop to define the lawful scope of such agreements. Nor could it do so. Such determination must of necessity follow the presentation of evidence designed to show what is necessary and proper to carry out the Congressional mandate. It seems clear that bona fide negotiations between carriers having as their objective the carrying out of this mandate fall within the lawful area of collaboration. It also seems clear that bona fide negotiations which are necessary and proper to carry out orders of the Interstate Commerce Commission, issued pursuant to the Congressional mandate placed on it with relation to the rates of carriers, are permissible. Such collective activities in rate making are made lawful because they facilitate the free flow of commerce; they become unlawful when they result in undue restraint of trade or in the monopolization of commerce. The test here would seem to be, to paraphrase a historic doctrine: let the end be legitimate, let it be within the scope of the Congressional mandate, and all means which are appropriate, which are plainly adapted to that end, which are not prohibited, but consistent with the letter and spirit of the mandate, are lawful.

There is then no need for abolishing rate bureaus whose activities are confined to such lawful purposes, nor for rate wars. Indeed, the existing regulatory scheme is designed to prevent rate wars through appropriate exercise of the Commission's minimum-rate power. Nor is there need for concern that carriers must, under the antitrust laws, make their rates "in a vacuum." That concept would clearly defeat the mandate of Congress. There is need, however, for a forthright study by the transportation industry of the proper area of collaboration necessary to carry out the Congressional mandate placed directly on the carriers in the making of ratesa factual study that would be of great aid in the present situation. This is the challenge implicit in the Supreme Court's decision in the Georgia case.

The transportation industry has not met this challenge. Denying the illegality of the practices that constitute the basis of the serious charges of conspiracy against the people of the South and the West in the Georgia and $A A R$ cases, the railroads generally, through the Association of American Railroads, have turned to Congress for relief from the antitrust laws for all their collective activities. Their latest effort is the so-called Reed-Bulwinkle Bill, designed to provide the means of exempting from the Sherman Act all agreements between carriers to fix collectively rates, classifications, divisions, allowances, time schedules, routes, the interchange of facilities, the settlement of claims, the promotion of safety, and "the promotion of adequacy, economy or efficiency of operation or service." ${ }^{2 B}$ Thus, according to the Department

${ }_{25} 24$ STAT. 380 ( 1887 ), as amended, 49 U. S. C. $\$ 6$ (I) (r940).

${ }^{28} \mathrm{~S}$. I Io, A Bill to Amend the Interstate Commerce Act with Respect to Certain Agrcements between Carriers, 8oth Cong., Ist Sess. (1947). Congress has repeatedly refused to enact legislation exempting rate conferences from the antiurust laws. First refusal, see 21 Conc. Rec. 4099, 4753, 5950, 5981, 6208, 63 I 4 (1890); second refusal, see I Sharfman, The Interstate Commerce Commission 52 (1931); third refusal, see Hearings before House Committee on Judiciary on Trust Legislation, 63d Cong., 2nd Sess. vol. 2, 894 (I9I4); 5 I Cong. Rec. 9285, 9286, 9582 (1914); Sex. Rep. No. 698, 63d Cong., 2nd Sess. 46, 60 (IgI4); 5 I CONG. REC. 14028 , I6264, I6344 (I914); fourth refusal, see Hearings before Senate Com- 
of Justice and the State of Georgia, the railroads seek to render moot the $A A R$ and Georgia cases. ${ }^{27}$

There are those in the railroad industry, however, who believe that competition within the framework of the regulatory scheme is essential to the continuance of private enterprise in that industry. ${ }^{28}$ They oppose complete Government regulation of the railroads as they do monopoly controls. They know that the railroads of the country have published trillions of rates and annually engage in hundreds of millions of different transactions involving millions of different individuals and corporations. They recognize (as the monopolists fail or refuse to recognize) that complete Government regulation of every aspect of this great mass of transactions would result in absolute Government control over the economic destinies of industry, labor, and agriculture-unless the regulated controls the regulator. In either event, the result would be the end of private enterprise in this basic industry, and its eventual nationalization.

In the view of the chief legal officer of one major railroad system, corrective action under the antitrust laws is essential to the welfare of the transportation industry. Recognizing that rate making by carriers presents a problem peculiar to the industry, this official testified that "as far as our philosophy is concerned, agreements on services and facilities which are of a competitive nature are against the public interest. They are things which bring the railroad industry down to the level of the poorest and lowest, and which are simply against the public interest. ... I want the committee to know insofar as those features of competitive service and facilities are concerned, I do not think that any legislation is necessary because I believe if those agreements are entered into which are unreasonable restraints that the antitrust laws should apply and that if agreements are entered into which are not unreasonable restraints of trade, then the antitrust laws do not apply. ... I do not understand that the antitrust laws prohibit carriers from discussing and considering their operating, engineering, and other problems or from entering into agreements or taking

mittee on S. 942, Regulation of Rate Bureaus, 78 th Cong., Ist Sess. (1943); fifth refusal, see Hearings before Senate Committee on H. R. 2536, Regulation of Rate Bureaus, 79th Cong., 2nd Sess. (1946). The Reed-Bulwinkle Bill (S. r ro, 8oth Cong., Ist Sess. (r947)), now pending in Congress, is the sixth attempt to set aside the antitrust laws as applied to rate making in transportation. As stated in the text, this bill goes beyond rate making, and covers every phase of public transportation by surface carriers.

${ }^{27}$ Hearings before Senate Committee on Intcrstate Commerce on $H . R$. 2536 , Regulation of Rate Bureaus, 79 th Cong., 2nd Sess. 423-424, 744 (I946).

${ }^{28} \mathrm{Mr}$. Robert R. Young, speaking for the Federation for Railway Progress, made the following statement concerning the Bulwinkle Bill: "The Federation for Railway Progress is opposed to the Bulwinkle Bill. We recognize for practical purposes the necessity of maintaining rate conferences in so far as they are suitably segulated. However, we are categorically opposed to any attempt to legalize other noncompetitive practices. For example, this bill would permit agreements among railroads to control such services to the traveler as air-conditioning, streamlining, flowers on dining car tables or even the degree of comfort to be provided in a train seat-with I.C.C. approval. We believe that such competitive services and facilities should be left to the individual initiative of each railroad." Railway Progress, April, x947, p. 5. The Association of American Railroads takes the opposite view. See Hearings before the Senate Committee on Interstate Commerce on H. R. 2536, Regulation of Rate Bureaus, 79th Cong., 2nd Sess. 1073, 1229, 1335, 1453 , and 2175 (1946). Hearings before the Committee on Interstate Commerce on S. IIo, Regulation of Rate Bureaus, 8oth Cong., ist Sess. 9, 123 (1947). 
other joint action respecting such matters which do not restrain trade or commerce.....229 It would seem that this spokesman within the industry has stated the basis upon which private operation of public transportation service can be justified in the public interest.

The controversy over the application of the antitrust laws to the transportation industry, particularly the railroads, since the decisions in the Georgia and $A A R$ cases, has become primarily a political one. Efforts have been intensified in Congress to provide the means of immunizing the transportation industry, and related interests, from the antitrust laws. Shall those who rule private companies operating public transportation services continue subject to corrective action under the antitrust laws or shall they be permitted to form combinations to control virtually every activity of this industry? This issue cannot be considered apart from its effect upon other businesses and the national economy, for transportation is the basic industry which supplies and controls every industrial and commercial activity. It is clear that those who dominate such combinations could dominate the national economy. Thus, the overriding issue before Congress is whether there shall be legalized monopolization of our transportation systems, with power to dominate the economic life of the nation, or competition within the framework of the regulatory scheme which will preserve private enterprise within that industry and the nation.

${ }^{29}$ Testimony of Robert W. Purcell, vice-president, Chesapeake \& Ohio Ry. Co., in Hearings before Committee on Interstate Commerce on S. 110, Regtlation of Rate Bureaus, 80th Cong., Ist Sess. 145-146, 163 (1947). 